\title{
Relationships Between Positive Parenting and Middle School Students' Cooperative Competence: Mediation Effects of Peer Relationships and Grit
}

\author{
Yangmi Lim \\ Associate Professor, Department of Home Economics Education, Jeonju University, Jeonju, Korea \\ 부모의 긍정적 양육행동이 중학생의 협동역량에 미치는 영향: \\ 또래관계 및 그릿의 매개효과 \\ 임양미 \\ 전주대학교 가정교육과 부교수
}

Objectives: The present study identified the direct effect of positive parenting on middle school students' cooperative competence and the mediating effects of peer relationships and grit on this process. This study also focused on the individual and sequential mediating processes of peer relationships and grit in the association between positive parenting and middle school students' cooperative competence.

Methods: Data were collected from 2,551 middle school first graders (boys: 1,383, girls: 1,168) who participated in the Korean Children and Youth Panel Survey 2018. Preliminary analyses were performed using descriptive statistics and correlation analysis. Structural equation modeling analysis using phantom variables with AMOS 25.0 program was conducted to examine a multiple mediation model the current study suggested.

Results: First, the direct effect of positive parenting on middle school students' cooperative competence was not significant. Second, positive parenting exerted an indirect effect on middle school students' cooperative competence through peer relationships and grit. Specifically, peer relationships and grit individually mediated the association between positive parenting and cooperative competence in the middle school students. Furthermore, peer relationships and grit played a sequential mediating role in linking positive parenting with cooperative competence in the middle school students. In other words, as parents showed positive parenting behaviors, adolescents formed positive peer relationships, which sequentially leads to promoting the development of grit and cooperative competence.

Conclusion: This study highlights that parents have an influence on adolescents' cooperative competence by facilitating high-quality peer relationships and grit development through the elements of positive parenting such as warmth, autonomy support, and structure.

Keywords: positive parenting, peer relationships, grit, cooperative competence

\section{Introduction}

지식정보사회에서 개인이 성공적인 삶을 살아가기 위해 기

Corresponding Author: Yangmi Lim, Associate Professor, Department of Home Economics Education, Jeonju University, 303, Cheonjam-ro, Wansan-gu, Jeonju, Jeonbuk, Korea

E-mail: ym68@jj.ac.kr
존의 산업사회와 차별화된 역량(competence)이 요구되고 있 다. 역량은 사회의 다양한 요구들에 적절히 대처하기 위해 필 요한 지식 및 기술, 태도를 포함한 종합적 능력으로 정의된다

(C)The Korean Association of Child Studies

This is an Open Access article distributed under the terms of the Creative Commons Attribution Non-Commercial License (http:// creativecommons.org/licenses/by-nc/4.0) which permits unrestricted noncommercial use, distribution, and reproduction in any medium, provided the original work is properly cited. 
(Rychen \& Salganik, 2003). 따라서 미래사회에서는 다양한 상 황에 효과적으로 대응하기 위해 지식의 단순한 수용이나 암기 보다 지식을 통합하고 적용하는 역량이 강조된다(Sung, Choi, $\mathrm{Kim}, \mathrm{Oh}, \& \mathrm{Jin}, 2015)$. 역량은 학교 뿐 아니라 가정, 지역사회 에서 학습되며, 이러한 학습은 청소년기에 활발하게 이루어 진다. 역량에 대한 연구는 2000년대 초 OECD Definition and Selection of Competencies (DeSeCo) 프로젝트를 시작으로 본격 화되었으며, 미래사회에서 요구되는 핵심역량으로 '자율적으 로 행동하기', '다양한 사회 집단에서 상호작용 하기', '도구를 사용해 상호작용 하기'로 제시되었다(C. H. Kim et al., 2013). 우리나라에서도 한국교육개발원 및 한국청소년정책연구원에 서 수행된 연구들을 통해, 청소년의 핵심역량으로 자기관리 및 계발역량, 학습역량, 대인관계역량, 시민참여역량이 제안 되었다(Sung et al., 2015).

이 중 대인관계역량의 한 유형인 협동역량은 입시경쟁의 가 열화로 교육현장에서 청소년의 인성 및 사회성 교육의 필요성 이 제기되면서 주목을 받아 왔다(J.-H. Park \& Hong, 2018). 협 동역량은 개인이 공동의 목표를 위해 집단 구성원들과 협력하 고 자신의 역할을 수행하며, 문제를 해결함으로써 집단성과 에 기여하는 능력이다. 특히 지식정보사회에서 이질적인 구성 원의 협동은 사회 성장과 발전에 핵심적인 요소로, $\mathrm{OECD}$ 를 비롯한 각국의 교육과정에서도 주요한 역량으로 다루고 있다 (Sung et al., 2015). 이러한 점은 소수 개인의 전문적 능력보다 다양성을 가진 집단의 지성(collective intelligence)이 미래 사회 운영에 필수적이라는 주장과 흐름을 같이 한다(H. Choi, Lee, $\& \mathrm{Kim}, 2020)$. 협동역량은 대인간 상호작용에서 요구되는 관 계형성역량과 개념적으로 다소 차이가 있다. 즉, 대인관계에서 요구되는 자기개방성, 친화성, 의사소통 및 공감과 배려는 미 시적 수준에서 타인과 긍정적인 관계를 맺는데 필요한 역량이 다. 반면 협동역량은 이러한 관계역량을 토대로 공동의 목표 달성을 위해 개인의 역할수행에 대한 자기조절(self-regulation) 과 더불어 다른 구성원과 공동의 목표와 과업 수행을 함께 점 검하며 타인의 행동을 조절하는 사회적 조절(socially-shared regulation)이 수반된다(Hadwin, Järvelä, \& Miller, 2017).

청소년기는 사춘기로 인한 발달적 변화와 함께 자신에게 몰 두하는 자기중심성과 집단 동일시 성향이 강하게 드러나는 시 기이다. 따라서 청소년기에는 자신의 이익을 추구하다가 또래 와 갈등이 발생할 가능성이 있으며, 이러한 또래와의 갈등은 부모 및 학교의 무관심, 비행 또래집단과의 결속 등의 조건에 서 또래 폭력의 형태로 종종 발전되기도 한다(M.-J. Lee \& Kim, 2018; Yang, Park, \& Lee, 2014). 학교 내·외에서 또래에 대한 다
양한 형태의 폭력은 학교폭력으로 개념화된다. 2019년 발표된 학교폭력실태조사 결과, 학교폭력 피해 응답률이 $1.6 \%$ 로 2018 년에 비해 $0.3 \%$ 증가하였고, 사춘기에 접어드는 초등학교 고 학년 및 중학교 시기의 학교폭력 발생률이 높았으며 같은 학교 및 학년의 또래집단에서 학교폭력이 발생되는 경향을 보였다 (Ministry of Education, 2019). 더욱이 학교교육은 교과 성적을 중심으로 경쟁적 분위기에서 실시됨으로써 타인과의 '관계'는 상실되었고, ‘공동체 의식'은 약화되었다. 따라서 교육부에서 는 이러한 문제를 해결하기 위해 2010년부터 초. 중등학교에 서 인성교육을 실시해 왔으나, 개인단위로 인성교육이 이루어 지며 협동역량 및 공동체 의식을 배양할 구체적 방안이 명확하 게 제시되지 못함으로써 아직까지 그 실효를 거두지 못하고 있 다(J.-H. Park \& Hong, 2018). 따라서 청소년의 협동역량 발달 을 위한 효과적 교육 방안 모색에 앞서 협동역량과 관련된 심 리 · 사회적 변인을 다각적으로 모색할 필요가 있다.

지금까지 수행된 선행 연구들을 살펴보면, 협동역량은 개 념적으로 구성 요소가 중복되는 다른 사회적 구인(예: 친사회 성)과 함께 다루어졌으며 협동역량에 초점을 맞춘 연구는 소 수(e.g., Jeon, 2020)에 불과하다. 그러나 이러한 연구 결과를 종 합해 보면, 협동역량에 대한 심리 - 사회적 변인들의 복합적 인 영향 경로를 추론할 수 있다. 부모는 청소년의 친사회성 및 협동, 대인관계역량에 영향을 미치는 대표적인 환경 변인이 다. 우선 부모는 친사회적 행동을 교육하거나 긍정적인 정서 표현과 양육행동을 통해 바람직한 사회적 행동의 모델이 됨 으로써 자녀의 대인관계역량 발달에 직접적으로 영향을 미친 다(Darling \& Steinberg, 1993). 구체적으로, 부모의 양육행동이 애정적이고 합리적이며 자녀의 자율성을 지지할수록 청소년 기 자녀는 타인에 대한 공감 및 협동, 대인관계갈등해결 수준 이 높았다(S. Lee \& Kwon, 2018; Yang et al., 2014). 더욱이 자녀 에게 애정 및 정서적 지지와 명확한 규칙을 제공하는 민주적 양육행동(authoritative parenting)은 정서적으로 지지적인 환경 에서 타인의 감정을 논의하고, 규칙설정에 대한 합리적 근거 를 제공함으로써 자녀의 협동심과 친사회성을 조장하는 것으 로 나타났다(Carlo, Mc Ginley, Hayes, Batenhortst, \& Wilkinson, 2007). 따라서 부모의 애정 및 자율성 지지, 합리적 규칙설정 이 자녀의 긍정적 대인관계능력 형성에 영향을 미치는 주요한 요인이라는 점이 제시되었다. 반면 S. Park, Park과 Kim (2018) 의 연구 결과, 부모의 양육행동이 비 일관적이고 과잉 기대와 간섭을 할수록 청소년기 자녀는 타인과 우호적인 관계를 유지 하고 권리를 주장하며 갈등을 해결하는 정도가 낮았다.

또한 부모의 양육행동이 청소년기 자녀의 친사회성 및 협 
동역량에 미치는 영향은 자녀의 사회적 - 심리적 요인을 통해 간접적으로 발생될 수 있다. 청소년기는 아동기에 비해 부모 로부터 독립하려는 욕구가 증가하며 학교에서 보내는 시간이 길어짐에 따라 또래와 심리적으로 밀착된다(Coleman, 1978). 전통적으로, 청소년기 부모와 또래관계는 보완적 - 경쟁적으 로, 부모로부터 충족되지 않은 욕구를 또래관계에서 보완하 며, 부모보다 또래애착 정도가 높아진다는 관점이 수용되어져 왔다. 그러나 점차 애착이론(Bowlby, 1982)의 영향으로 부모와 의 관계의 질이 청소년기 또래관계의 질을 예측한다는 연속적 관점이 지지를 받고 있다(Wilkinson, 2004). 애착이론에 의하 면, 영아기부터 형성된 주 양육자인 부모에 대한 애착이 자아 와 타인에 대한 내적 실행모델(internal working model)을 통해 아동기 및 청소년기 자녀의 사회 · 정서 발달에 영향을 미치게 된다(Bowlby, 1982). 즉, 부모의 양육행동이 온정적이고 지지 적일수록, 자녀는 자신과 타인을 긍정적으로 인식하고 부모에 대한 정서적 안정감과 신뢰감을 또래관계에 전이시켜 또래와 긍정적인 관계를 맺게 된다(Gorrese \& Ruggieri, 2012; Llorca, Cristina Richaud, \& Malonda, 2017). 더욱이 또래와 긍정적인 관계를 형성할수록, 청소년은 또래로부터 학교생활적응에 필 요한 도구적 - 정서적 지원을 제공받고, 또래관계를 통해 사회 구조를 인식하며 타인과의 관계에서 수용되는 것이 어떠한 것 인지를 학습할 수 있으므로 친사회성 및 협동역량이 발달된다 (H.-L. Kim, Kim, \& Chung, 2011; Schoeps, Mónaco, Cotolí, \& Montoya-Castilla, 2020). 이와 같이 애착이론은 부모-자녀 관 계의 질이 청소년의 또래관계로 전이되는 과정을 설명한 반 면 몇몇 학자들(Goodwin, Mrug, Borch, \& Cillessen, 2012; Shin, 2017)은 청소년 스스로 유사한 성향을 가진 또래를 선택함으 로써 부모와의 관계를 통해 형성된 사회적 성향이 강화되는 과정을 설명한다. 구체적으로, 청소년은 스스로 자신과 유사 한 행동성향과 가치관을 보이는 또래를 친구로 선택하는 호모 필리(homophily) 성향을 보이므로, 타인에 대해 우호적인 청 소년은 친사회적 성향을 가진 또래를 선택하여 상호작용함으 로써 협동 등의 친사회적 성향이 더욱 강화된다(Shin, 2017). 따라서 이러한 연구 결과를 종합해 보면, 온정적이고 지지적 인 부모의 긍정적 양육행동이 또래관계를 통해 자녀의 협동역 량에 간접적으로 영향을 미치는 경로가 예측된다.

한편 협동은 목표가 있는 사회 집단에서 발생하며, 목표달 성에 대한 열정 및 노력과 자기통제의 요소를 포함한다(Sung et al., 2015). 이러한 점에서 그릿(grit)은 부모의 양육행동과 자녀의 협동역량을 매개하는 역할을 수행할 수 있다. 그릿 은 최근 교육학 및 심리학 분야에서 주목을 받고 있는 심리적
구인으로, 목표에 대한 흥미유지와 목표달성을 위한 지속적 인 노력, 2 개의 하위요인으로 구성된다(Duckworth, Peterson, Matthews, \& Kelly, 2007). 따라서 그릿은 목표에 대한 흥미와 열정을 유지하면서 목표달성을 위해 장애물을 극복하고 노력 을 유지하는 것으로, 유사한 개념으로 성실성과 자기통제 등 이 있다(Duckworth et al., 2007). 그릿은 2007년 미국의 Angela Duckworth와 동료들에 의해서 처음 소개된 개념으로, 국내에 서는 원어가 내포한 개념을 대표할 단어가 적당하지 않아 원 어 그대로 사용하고 있다. 그릿은 학교, 결혼 및 직장 등 다양 한 사회적 상황에서 개인의 성공과 긍정적 적응과 관련된 변 인이라는 점이 여러 연구들을 통해 제시되었다(Duckworth et al., 2007; Eskreis-Winkler, Shulman, Beal, \& Duckworth, 2014). 또한 그릿은 긍정적인 부모의 양육을 통해 발달되며, 타인에 대한 친사회적 행동에 영향을 미치는 것으로 보고되고 있다. 구체적으로, 부모의 자녀에 대한 애정과 존중 및 기대 수준이 높을수록, 그리고 부모와 안정적 애착을 형성할수록 자녀의 그릿 발달을 촉진하는 것으로 나타났으며(Duckworth, 2016; Kang \& Yang, 2019), 부모의 거부나 강요 또는 학대는 그릿 발 달에 부정적인 영향을 미쳤다(E. H. Kim \& Kim, 2020; King et al., 2020). 또한 그릿 수준이 높을수록 타인을 돌보고 협동하 는 친사회적 성향이 높은 것으로 나타났다(Duckworth, 2016; Lan, Marci, \& Moscardino, 2019; Ryu \& Yang, 2017). 그러므로 그릿은 부모의 긍정적 양육행동이 자녀의 협동역량에 미치는 영향을 매개할 것으로 가정된다.

이상에서 제시된 바와 같이 자녀의 또래관계와 그릿은 부 모의 양육행동이 협동역량에 영향을 미치는 과정에서 개별적 인 매개역할을 수행할 뿐 아니라, 순차적(sequential) 매개역할 도 수행할 수 있다. 또래관계와 그릿의 순차적 매개역할은 애 착이론 및 또래관계와 그릿 발달 간의 관련성을 규명한 여러 연구들을 통해 가정된다. 애착이론에 의하면, 또래와 같은 애 착대상은 개인이 목표 및 과업달성을 위해 노력하는 과정에 서 심리적 안정의 기반(secure base)을 제공하므로(Armsden \& Greenberg, 1987), 긍정적인 또래관계는 목표달성을 위한 노 력과 자기통제의 요인을 내포한 그릿 발달을 촉진한다(Jin, Wang, \& Lan, 2019). 이러한 주장은 몇몇 연구(Han \& Park, 2018; Lan, 2019)를 통해 또래의 지지 및 또래에 대한 애착 수 준이 높을수록 청소년의 그릿 수준이 높은 것으로 보고됨으로 써 지지되었다. 더욱이 그릿의 구성 요인인 자기통제 또는 목 표달성을 위한 노력에 대한 또래관계의 영향을 종단적 또는 실험 연구 설계를 통해 탐색한 여러 연구들(King, Mc Laughlin, Silk, \& Monahan, 2018; Mc Laughlin, Hatzenbuehler, \& Hilt, 
2009; Meldrum \& Hay, 2012)을 통해 또래관계가 그릿에 영향 을 미치는 경로가 규명되었다. 즉, 아동 및 청소년의 긍정적 인 또래관계는 이후의 자기통제 수준에 정적인 영향을 미쳤 으며(Mc Laughlin et al., 2009; Meldrum \& Hay, 2012), 사전 · 사 후 실험을 통해 청소년이 또래와 긍정적인 상호작용을 경험 한 경우 자기통제 수준이 향상된 반면 또래로부터 거부될 경 우 과업수행의 지속성이 저하된 것으로 나타난 연구(King et al., 2018)도 존재한다. 따라서 이러한 연구 결과와 더불어 앞 서 언급된 부모의 긍정적 양육행동이 청소년의 또래관계에 미 치는 영향(Gorrese \& Ruggieri, 2012; Llorca et al., 2017) 및 그릿 과 친사회성 간의 관계(Duckworth, 2016; Lan et al., 2019; Ryu $\&$ Yang, 2017)를 보고한 여러 연구 결과를 종합해 볼 때, 부모 의 긍정적 양육행동이 또래관계와 그릿의 순차적 매개를 통해 협동역량에 영향을 미치는 경로가 추측된다.

지금까지 협동역량에 대한 부모, 또래 및 그릿의 영향을 살 펴본 연구들은 다음과 같은 경향을 보인다. 우선 청소년의 협 동역량 또는 친사회성, 대인관계역량에 초점을 맞추어 부모 및 또래관계, 그릿의 영향력을 살펴본 연구들은 대부분 한 두 가지 변인에 초점을 맞추어 변인들의 독립적 또는 상대적 영 향력을 분석한 반면(e.g., Malonda, Llorca, Mesurado, Samper, \& Mestre, 2019), 부모와 또래관계, 그릿이 협동역량에 영향을 미 치는 복합적인 경로를 규명한 시도는 아직까지 이루어지지 않 았다. 특히 협동역량의 경우 사회 집단에서 목표 달성을 위해 자신 및 타인의 행동과 정서 등에 대한 협력적 조절을 수반하 는 점에서 미시적 수준의 다른 대인관계역량과 개념상 차이가 존재하므로, 협동역량에 초점을 맞추어 관련된 사회적 - 심리 적 변인들의 영향 경로를 탐색해 보는 과정이 필요하다. 또한 지금까지 협동역량에 초점을 둔 연구들(Gil \& Yu, 2020; Jeon, 2020)은 주로 아동 또는 성인을 대상으로 부모 및 개인내적 변 인(예: 그릿, 문제해결역량 등)의 영향을 규명함으로써 협동역 량 함양이 주요한 발달과업으로 대두되는 청소년기에 수행된 연구는 찾아보기 힘들었다.

따라서 본 연구는 다원화된 미래사회에서 필요한 핵심역량 인 협동역량에 초점을 맞추어 교육환경 및 대인관계의 변화 가 크게 일어남으로써 긍정적 또래관계 형성과 협동이 주요한 발달과업으로 대두되는 중학교 1학년을 대상으로, 부모의 긍 정적 양육행동이 청소년의 협동역량에 미치는 직접적 영향과 또래관계와 그릿을 통한 간접적 영향을 살펴보고자 한다. 특 히 부모의 긍정적 양육행동이 또래관계와 그릿을 통해 협동 역량에 영향을 미치는 경우 선행 연구 결과를 통해 가정된 3 개의 경로(부모의 긍정적 양육행동 $\rightarrow$ 또래관계 $\rightarrow$ 협동역량,
부모의 긍정적 양육행동 $\rightarrow$ 그릿 $\rightarrow$ 협동역량, 부모의 긍정적 양육행동 $\rightarrow$ 또래관계 $\rightarrow$ 그릿 $\rightarrow$ 협동역량)를 규명하고자 한 다. 또한 본 연구에서는 선행 연구(Carlo et al., 2007; S. Lee \& Kwon, 2018; Yang et al., 2014)를 통해 친사회성 및 협동역량과 관련이 있는 것으로 제시된 부모의 애정 및 자율성 지지, 구조 제공을 긍정적 양육행동의 구성 요소로 선정하였다. 본 연구 의 연구문제 및 연구모델(Figure 1)은 다음과 같다.

\section{연구문제 1}

부모의 긍정적 양육행동은 중학생의 협동역량에 직접적으로 영향을 미치는가?

\section{연구문제 2}

부모의 긍정적 양육행동은 또래관계 및 그릿을 통해 중학생 의 협동역량에 간접적으로 영향을 미치는가?

2-1. 부모의 긍정적 양육행동은 또래관계를 매개로 중학생의 협동역량에 간접적으로 영향을 미치는가?

2-2. 부모의 긍정적 양육행동은 그릿을 매개로 중학생의 협동 역량에 간접적으로 영향을 미치는가?

2-3. 부모의 긍정적 양육행동은 또래관계와 그릿의 순차적 매 개를 통해 중학생의 협동역량에 간접적으로 영향을 미치는가?

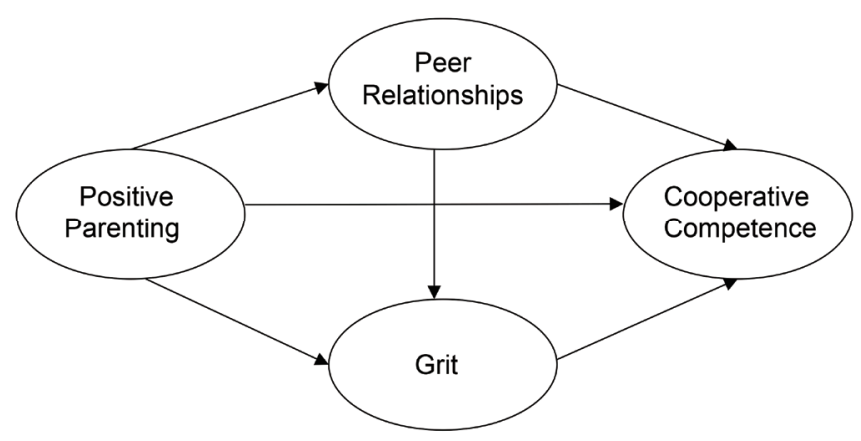

Figure 1. Research model.

\section{Methods}

\section{연구대상}

본 연구대상은 한국청소년정책연구원에서 실시한 한국 아 
Table 1

Demographic Characteristics of Participants

\begin{tabular}{|c|c|c|c|}
\hline Variables & Categories & Frequency & $(\%)$ \\
\hline \multirow[t]{6}{*}{ Fathers' education levels } & Middle school graduation or less & 39 & $(1.6)$ \\
\hline & High school graduation & 753 & $(31.0)$ \\
\hline & College graduation & 491 & $(20.2)$ \\
\hline & University graduation & 899 & $(37.0)$ \\
\hline & Graduate school graduation & 249 & $(10.2)$ \\
\hline & Totals & 2,431 & $(100.0)$ \\
\hline \multirow[t]{6}{*}{ Mothers' education levels } & Middle school graduation or less & 60 & ( 2.4) \\
\hline & High school graduation & 883 & $(35.6)$ \\
\hline & College graduation & 646 & ( 26.1) \\
\hline & University graduation & 757 & $(30.5)$ \\
\hline & Graduate school graduation & 133 & $(5.4)$ \\
\hline & Totals & 2,479 & $(100.0)$ \\
\hline \multirow{7}{*}{$\begin{array}{l}\text { Average monthly household income } \\
(10,000 \mathrm{KRW})\end{array}$} & Less than 100 & 38 & $(1.5)$ \\
\hline & $100 \sim$ less than 300 & 340 & $(13.3)$ \\
\hline & $300 \sim$ less than 500 & 948 & $(37.2)$ \\
\hline & $500 \sim$ less than 700 & 728 & $(28.5)$ \\
\hline & $700 \sim$ less than 900 & 284 & $(11.1)$ \\
\hline & More than 900 & 213 & $(8.3)$ \\
\hline & Totals & 2,551 & $(100.0)$ \\
\hline \multirow[t]{11}{*}{ Fathers' occupation } & Manager & 345 & $(14.8)$ \\
\hline & Professional & 512 & $(21.9)$ \\
\hline & Office worker & 458 & $(19.6)$ \\
\hline & Service worker & 243 & $(10.4)$ \\
\hline & Sales worker & 146 & $(6.2)$ \\
\hline & Agricultural, forestry, and fishery worker & 71 & $(3.0)$ \\
\hline & Craft worker & 229 & $(9.8)$ \\
\hline & Equipment, machine operating, and assembling worker & 198 & $(8.5)$ \\
\hline & Elementary worker & 63 & $(2.7)$ \\
\hline & Others & 73 & $(3.1)$ \\
\hline & Totals & 2,338 & $(100.0)$ \\
\hline \multirow[t]{11}{*}{ Mothers' occupation } & Manager & 82 & $(4.5)$ \\
\hline & Professional & 543 & $(30.0)$ \\
\hline & Office worker & 395 & $(21.8)$ \\
\hline & Service worker & 404 & $(22.3)$ \\
\hline & Sales worker & 164 & $(9.1)$ \\
\hline & Agricultural, forestry, and fishery worker & 37 & $(2.0)$ \\
\hline & Craft worker & 47 & $(2.6)$ \\
\hline & Equipment, machine operating, and assembling worker & 25 & $(1.4)$ \\
\hline & Elementary worker & 95 & $(5.2)$ \\
\hline & Others & 18 & $(1.0)$ \\
\hline & Totals & 1,810 & $(100.0)$ \\
\hline
\end{tabular}


동 - 청소년 패널 조사 2018에 참여한 중학교 1학년 학생이 었다. 한국 아동 · 청소년 패널 조사 2018은 2003년과 2010년 에 실시된 한국 아동 ·청소년 패널 조사의 후속조사로, 2018 년 전국의 중학교 1학년 학생을 모집단으로 하여 다단계 층화 집락표집 방식으로 표본이 추출되었다(National Youth Policy Institute [NYPI], 2018). 본 연구는 선정한 변인들에 대해 결측 치를 포함한 경우를 제외한 총 2,551명(남학생: 1,383 명, 여학 생: 1,168명)을 최종 연구대상으로 선정하였다.

본 연구대상의 평균연령은 12.99 세 $(S D=.13)$ 이었으며, 인구 통계학적 배경은 Table 1에 제시된 바와 같다. 본 연구대상 아버 지와 어머니 학력의 경우 대학교 졸업자가 각각 $57.2 \%, 56.6 \%$ 로 과반수를 차지하였으며, 월평균 가구소득은 300-500만원 미만(37.2\%)과 500-700만원 미만(28.5\%)이 가장 많았다. 또한 아버지 직업의 경우 전문직(21.9\%) 및 사무직(19.6\%), 관리직 $(14.8 \%)$ 종사자가 많았으며 어머니의 경우 전문직(30.0\%) 및 서비스직(22.3\%), 사무직(21.8\%) 종사자가 많았다.

\section{연구도구}

\section{협동역량}

본 연구대상의 협동역량은 T. Kim, Oh와 Lee (2015)가 개발한 협동(14문항) 척도를 사용하여 측정되었다. 협동 척도는 다른 집단 구성원이 맡은 역할을 잘 수행할 수 있도록 돕는 집단촉 진(6문항; 문항의 예: "그룹활동을 할 때, 친구의 장점이나 능 력을 적극적으로 알려준다.”), 집단의 구성원으로서 집단의 비 전과 목표를 공유하며 목표달성을 위해 자신의 역할을 수행하 는 팔로워십(3문항; 문항의 예: “그룹활동을 할 때, 나의 역할 에 최선을 다한다.”), 집단 내 갈등상황을 바람직하게 해결하 기 위해 구성원과 상호작용하고 협동하는 갈등문제해결(5문 항; 문항의 예: “그룹에서 발생한 문제와 관련된 지식이나 정 보를 친구들과 공유한다.”), 3 개의 하위요인으로 이루어져 있 다. 각 문항은 4점 척도로, 모든 문항은 그대로 채점하였다. 본 연구에서는 구조방정식모델 분석 시, 협동역량의 지표로 집단 촉진, 팔로워십, 갈등문제해결을 사용하였다. 협동 척도의 점 수범위는 집단촉진 하위요인의 경우 6-24점, 팔로워십 하위 요인의 경우 3-12점, 갈등문제해결 하위요인의 경우 5-20점으 로 점수가 높을수록, 집단의 목표를 이루기 위해 자신의 역할 을 잘 수행하고 타인을 도우며, 문제가 있을 경우 해결하기 위 해 다른 구성원과 함께 노력하는 정도가 높음을 의미한다. 협 동 척도의 전체 내적합치도 계수(Cronbach's $\alpha$ )는 .94이었으며,
집단촉진 하위요인의 경우 .88 , 팔로워십 하위요인의 경우 .82 , 갈등문제해결 하위요인의 경우 .88 이었다.

\section{긍정적 양육행동}

본 연구대상이 지각한 부모의 긍정적 양육행동은 T. Kim과 Lee (2017)가 개발한 척도를 사용하여 측정되었다. 본 연구에 서 사용한 척도는 각각 4 문항으로 이루어진 3 개의 하위요인, 따스함(문항의 예: "부모님이 나를 사랑한다는 것을 표현하신 다.”), 자율성 지지(문항의 예: “부모님은 나를 믿어주신다.”), 구조제공(문항의 예: "내가 무언가 하려고 할 때, 부모님이 어 떻게 하라고 가르쳐 주신다.”)으로 구성되어 있다. 각 문항은 4 점 척도로, 모든 문항은 그대로 채점하였다. 본 연구에서는 구 조방정식모델 분석 시, 부모의 긍정적 양육행동의 지표로 따 스함, 자율성 지지, 구조제공을 사용하였다. 각 하위요인의 점 수범위는 모두 4-16점으로 점수가 높을수록 부모가 자녀에게 애정 및 관심을 표현하고 자율성을 지지하며 자녀의 행동에 대한 지도 및 사회적 규범을 설명하는 정도가 높음을 의미한 다. 긍정적 양육행동 척도의 전체 내적합치도 계수(Cronbach's $\alpha$ )는 .92이었으며, 따스함 하위요인의 경우 .91, 자율성 지지 하위요인의 경우 .88 , 구조제공 하위요인의 경우 .80 이었다.

\section{또래관계}

본 연구대상의 또래관계를 평가하기 위해 Bae, Hong과 Hyun (2015)이 개발한 또래관계 질 척도를 사용하였다. 또래관계 질 척도는 또래와 긍정적 관계 및 부정적 관계의 질을 측정하 는 문항으로 구성되어 있다. 긍정적 관계 하위요인은 상호친 밀감, 사회적 지지 및 또래관계에 대한 만족을 측정하는 8문항 (예: “친구들과의 관계가 좋다.”)으로 이루어져 있으며, 부정적 관계 하위요인은 또래와 갈등과 대립, 또래관계의 일방적 주 도, 고립을 측정하는 5 문항(예: “친구와 싸우면 잘 화해하지 않 는다.”)으로 이루어져 있다. 각 문항은 4점 척도로, 부정적 관 계 하위요인에 한해 역채점을 수행하였다. 본 연구에서는 구 조방정식모델 분석 시, 또래관계의 지표로 긍정적 관계 하위 요인과 부정적 관계 하위요인을 투입하였다. 또래관계 척도의 점수범위는 긍정적 또래관계 하위요인의 경우 8-32점, 부정적 또래관계 하위요인의 경우 5-20점으로, 점수가 높을수록 또래 와 긍정적 관계를 형성하고 또래관계의 부정적 측면(갈등과 대립, 일방적 주도, 고립)의 수준이 낮음을 의미한다. 또래관 계 척도의 전체 내적합치도 계수(Cronbach's $\alpha$ )는 .85이었으며, 
긍정적 관계 하위요인의 경우 .90 , 부정적 관계 하위요인의 경 우.74이었다.

\section{그릿}

본 연구대상의 그릿은 Duckworth와 Quinn (2009)이 개발한 척도에 대해 H.-M. Kim과 Hwang (2015)이 번안한 척도를 사 용하여 측정되었다. 그릿 척도는 흥미유지(4문항; 문항의 예: "나는 어떤 문제에 잠깐 집중하다가 곧 흥미를 잃은 적이 있 다.”)와 노력지속(4문항; 문항의 예: "나는 시작하면 무조건 끝 낸다.”)을 측정하는 총 8 문항으로 구성되어 있다. 각 문항은 4 점 척도로, 흥미유지에 속하는 4문항에 한해 역채점을 수행하 였다. 본 연구에서는 구조방정식모델 분석 시, 그릿의 지표로 흥미유지와 노력지속 하위요인을 투입하였다. 흥미유지와 노 력지속 하위요인의 점수범위는 각각 4-16점으로, 점수가 높을 수록 목표를 이루기 위해 관심과 흥미를 유지하고 노력하는 정도가 높음을 의미한다. 그릿 척도의 전체 내적합치도 계수 (Cronbach's $\alpha$ )는 .71이었으며, 흥미유지 하위요인의 경우 .70, 노력지속 하위요인의 경우 .64이었다.

\section{자료분석}

수집된 자료는 SPSS Statistics 및 AMOS 25.0 프로그램(IBM Co., Armonk, NY)을 통해 분석되었다. 우선 연구대상의 인구 통계학적 배경과 연구변인들의 일반적 경향을 살펴보기 위해 기술통계(빈도분석, 평균 및 표준편차, 왜도 및 첨도)를 산출 하였으며, 부모의 긍정적 양육행동, 또래관계, 그릿, 협동역량 간의 관계를 알아보기 위해 상관관계 분석을 수행하였다.

연구문제에서 제시된 부모의 긍정적 양육행동이 중학생의 협동역량에 미치는 직접적 영향과 또래관계와 그릿을 통한 간 접적 영향을 알아보기 위해 구조방정식모델 분석을 실시하였 다. 구조방정식모델 분석 시, 최대우도법(maximum likelihood estimation)을 적용하였으며, 모델의 적합도는 표본크기에 대한 민감성과 모델의 간명성을 고려하여 Comparative Fit Index (CFI), Normed Fit Index (NFI), Root Mean Square Error of Approximation (RMSEA) 지수를 사용하여 평가하였다. 모 델의 CFI 및 NFI가 .90 이상, RMSEA가 .08 이하일 경우 적합 한 수준을 의미한다(Yu, 2012). 특히 구조방정식모델 분석 시, 부모의 긍정적 양육행동이 중학생의 협동역량에 미치는 영향 에 있어 또래관계와 그릿의 매개역할을 알아보기 위해 부트 스트랩핑(bootstrapping)을 수행하였다. 그러나 부트스트랩핑
은 부모의 긍정적 양육행동이 또래관계와 그릿을 통해 협동역 량에 영향을 미치는 전반적인 간접적 경로에 대한 통계적 유 의도만 제시할 뿐 또래관계 및 그릿의 다중 매개경로 각각에 대한 통계적 유의도를 입증하지 못한다. 본 연구는 이러한 문 제를 해결하고자 팬텀변수(phantom variables)를 사용하였다. 팬텀변수는 모든 매개과정 각각에 대한 통계적 검증을 위해 사용되며, 모델의 적합도에 영향을 미치지 않는다(Macho \& Ledermann, 2011). 따라서 본 연구에서는 가정한 3개 경로(부 모의 긍정적 양육행동 $\rightarrow$ 또래관계 $\rightarrow$ 협동역량, 부모의 긍정 적 양육행동 $\rightarrow$ 그릿 $\rightarrow$ 협동역량, 부모의 긍정적 양육행동 $\rightarrow$ 또래관계 $\rightarrow$ 그릿 $\rightarrow$ 협동역량) 각각에 대해 팬텀변수를 사용 하여 이에 대한 부트스트랩핑을 수행하였다. 한편 본 연구는 구조방정식모델 분석 시, 연구변인 외 협동역량에 영향을 미 치는 것으로 보고된(Chang \& Chung, 2013; K. O. Choi, 2015) 가정의 경제적 수준, 학교생활만족을 통제변수로 지정하였다. 가정의 경제적 수준은 앞서 제시한 월평균 가구소득 문항을 토대로 측정되었으며, 학교생활만족도는 전반적인 학교생활 만족도를 묻는 1 문항(5점 척도)으로 측정되었다.

\section{Results}

\section{예비분석}

본 연구변인인 부모의 긍정적 양육행동, 또래관계, 그릿, 협동 역량의 평균과 표준편차, 왜도 및 첨도, 상관관계 분석결과는 Table 2에 제시되어 있다. 본 연구대상이 지각한 부모의 긍정 적 양육행동 하위요인(따스함, 자율성 지지, 구조제공) 문항평 균은 $3.06(S D=.54) \sim 3.37(S D=.57)$ 로 가능한 점수(1-4점)를 고려해 볼 때, 비교적 높은 수준이었다. 또한 또래관계의 경우 긍정적 또래관계 및 부정적 또래관계 하위요인 문항평균은 각 각 $3.11(S D=.53)$ 과 $3.15(S D=.52)$ 로 가능한 점수(1-4점)를 고려해 볼 때, 비교적 높은 수준이었다. 반면 그릿의 경우 흥미 유지 하위요인 $(M=2.62, S D=.55)$ 과 노력지속 하위요인 $(M=$ $2.70, S D=.53)$ 문항평균은 중간 수준보다 다소 높았다. 그리 고 협동역량 하위요인들의 문항평균(4점 척도)은 2.90 ( $S D=$ .56) 3.14 $(S D=.57)$ 로 모두 중간 수준 이상이며, 집단촉진 문 항평균이 다른 하위요인에 비해 다소 낮았다.

본 연구의 자료가 구조방정식모델 분석을 수행할 경우 요 구되는 다변량 정상성 가정을 충족시키는지 알아보기 위해 연 구변인들의 왜도 및 첨도를 살펴본 결과, 정상성 기준(왜도 절 
Table 2

Descriptive Statistics and Correlations Among Variables

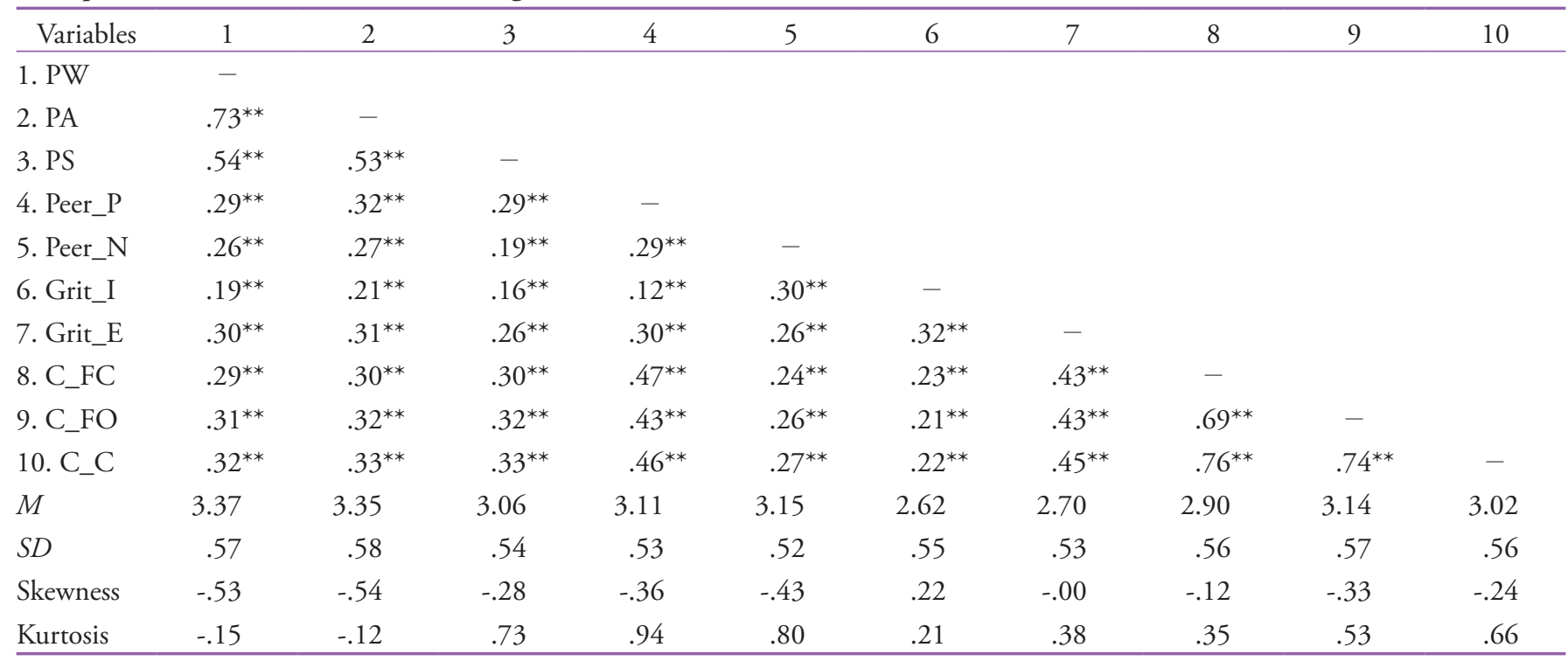

Note. $N=2,551.1$ = PW: warmth (positive parenting); 2 = PA: autonomy support (positive parenting); 3 = PS: structure (positive parenting); 4 = Peer_P: positive peer relationships; $5=$ Peer_N: negative peer relationships; $6=$ Grit_I: consistency of interest; $7=$ Grit_E: perseverance of effort; 8 = C_FC: group facilitation (cooperative competence); 9 = C_FO: followership (cooperative competence); $10=$ C_C: conflict resolution (cooperative competence).

${ }^{* *} p<.01$.

대값 < 2, 첨도 절대값 < 7; West, Finch, \& Curran, 1995)을 충 족시켰다. 한편 구조방정식모델 분석에 앞서 연구변인들 간의 상관관계 분석을 수행한 결과, 부모의 긍정적 양육행동은 협 동역량 $(.29 \leq r \leq .33, p<.01)$, 또래관계 $(.19 \leq r \leq .32, p<.01)$ 및 그릿 $(.16 \leq r \leq .31, p<.01)$ 과 통계적으로 의미 있는 정적 상관 관계가 있었으며, 또래관계(.24 $\leq r \leq .47, p<.01)$ 와 그릿(. $21 \leq$ $r \leq .45, p<.01)$ 은 각각 협동역량과 유의미한 정적 상관관계가 보고되었다. 또한 또래관계와 그릿 간에도 정적 상관관계(.12 $\leq r \leq .30, p<.01)$ 가 제시되었다.

\section{부모의 긍정적 양육행동이 중학생의 협동역량 에 미치는 직접적 영향과 또래관계와 그릿을 통한 간접적 영향}

본 연구문제 분석에 앞서 본 연구의 도구가 해당 잠재변인들 을 잘 측정하는지 알아본 결과, 측정모델의 적합도는 적절한 수준이었다 $\left(\chi^{2}=274.079, d f=29, \mathrm{CFI}=.976, \mathrm{NFI}=.974, \mathrm{RM}-\right.$ $\mathrm{SEA}=.058)$. 또한 확인적 요인분석을 통해 각각의 잠재변인에 대한 측정변인의 설명력을 의미하는 표준 요인부하량을 살펴 본 결과, 또래관계 척도 부정적 또래관계 하위요인과 그릿 척 도 흥미유지 하위요인에 속하는 몇몇 문항의 표준 요인부하량
이 .50 미만으로, 통계학자들(Yu, 2012)이 제시한 수렴타당도 기준치(.50)에 도달하지 못하였다. 비록 요인부하량 수치를 낮 추는 문항을 제거함으로써 측정치의 일관성을 높일 수 있으 나, 이러한 기준치는 권장 수치로 절대 수치가 아니며 문항 수 가 비교적 적은 상태에서 문항을 삭제할 경우 구성개념에 대 한 본래의 의미가 달라질 수 있다(Yu, 2012). 특히 본 연구에서 요인부하량이 낮은 문항들이 속하는 그릿의 흥미유지 및 부정 적 또래관계 하위요인 문항 수가 많지 않으며, 해당 문항(“나 는 자주 목표를 세우지만 그것을 이루기 전에 다른 목표를 세 우고는 한다.”, “친구들과 의견 충돌이 잦다.”)의 경우 표준 요 인부하량이 .50 에 인접하며, 문항이 측정하는 잠재변인의 구 성개념에 필요한 문항으로 판단되어 그대로 사용하였다.

한편 본 연구문제 1,2 에서 제시된 부모의 긍정적 양육행동 과 또래관계 및 그릿이 중학생의 협동역량에 영향을 미치는 경로를 알아보기 위해 구조방정식모델 분석을 실시하였다. 우 선 연구모델의 적합도 $\left(\chi^{2}=314.067, d f=44, \mathrm{CFI}=.975, \mathrm{NFI}=\right.$ $.971, \mathrm{RMSEA}=.049)$ 는 우수한 수준이었다. 또한 부모의 긍정 적 양육행동이 중학생 자녀의 협동역량에 미치는 직접적 영 향과 또래관계 및 그릿을 통한 간접적 영향을 구체적으로 살 펴본 결과는 Table 3과 Figure 2에 제시되어 있다. 그 결과, 부 모의 긍정적 양육행동은 협동역량에 직접적으로 영향을 미치 
Table 3

Path Estimates in the Structural Model

\begin{tabular}{lcccc}
\hline \multicolumn{1}{c}{ Paths } & $B$ & $\beta$ & $S E$ & CR \\
\hline Positive parenting $\rightarrow$ Cooperative competence & -.10 & -.07 & .06 & -1.76 \\
Positive parenting $\rightarrow$ Peer relationships & .51 & $.49^{* * *}$ & .03 & 15.77 \\
Positive parenting $\rightarrow$ Grit & .12 & $.17^{* * *}$ & .03 & .03 \\
Peer relationships $\rightarrow$ Cooperative competence & .96 & $.68^{* * *}$ & .12 & .07 \\
Grit $\rightarrow$ Cooperative competence & .66 & $.30^{* * *}$ & .11 & .03 \\
Peer relationships $\rightarrow$ Grit & .36 & $.54^{* * *}$ & .04 & 8.94 \\
\hline
\end{tabular}

Note. $N=2,551$.

*** $p<.001$.

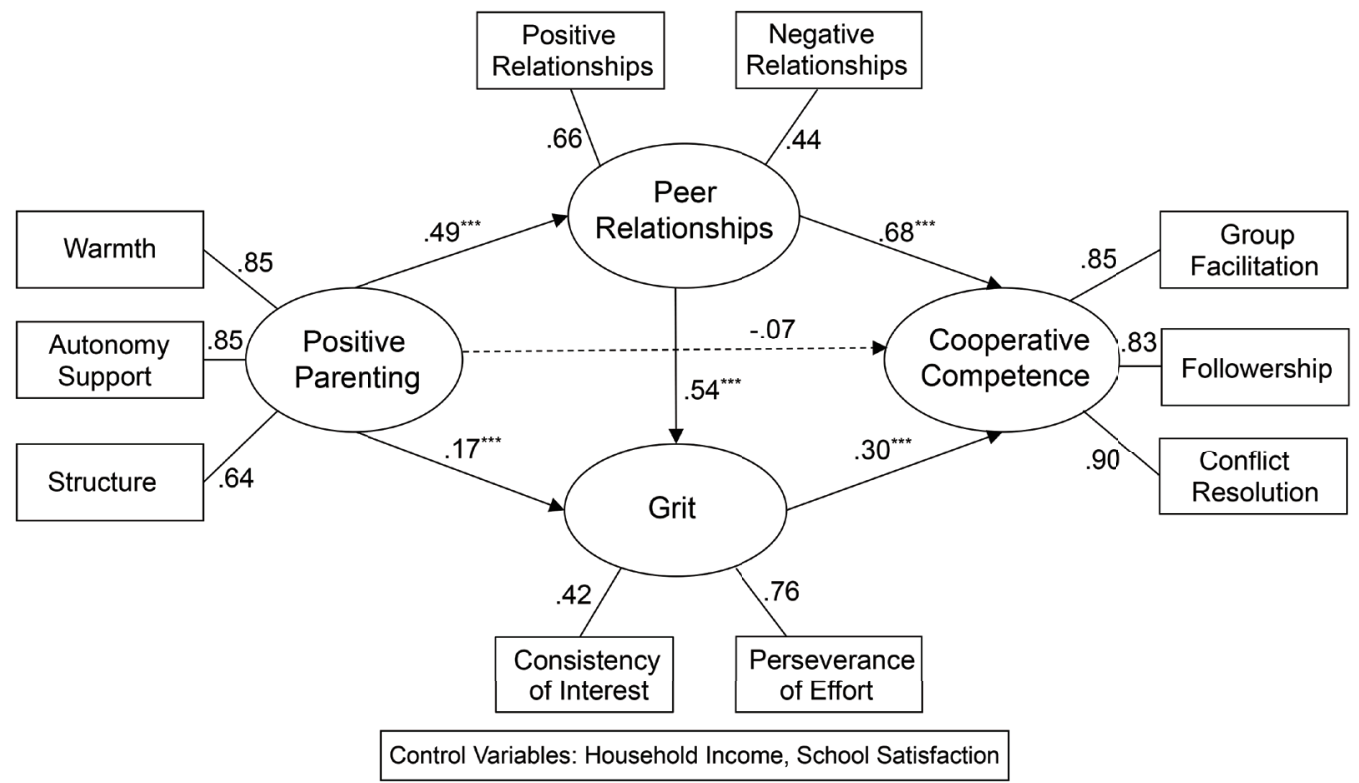

Figure 2. Standardized coefficients in the structural model.

$N=2,551$.

*** $p<.001$.

Table 4

Statistical Significance of Indirect Paths

\begin{tabular}{lcc}
\hline \multicolumn{1}{c}{ Indirect paths } & \multicolumn{1}{c}{$B$} \\
\hline Positive parenting $\rightarrow$ Peer relationships $\rightarrow$ Cooperative competence & $.41^{*}$ & $.09^{*}$ \\
Positive parenting $\rightarrow$ Grit $\rightarrow$ Cooperative competence & $.11^{* *}$ \\
Positive parenting $\rightarrow$ Peer relationships $\rightarrow$ Grit $\rightarrow$ Cooperative competence &
\end{tabular}

Note. $N=2,551$.

${ }^{*} p<.05 .{ }^{* *} p<.01$.

지 못한 반면(연구문제 1), 연구문제 2에서 제시된 부모의 긍

정적 양육행동이 또래관계 및 그릿을 통해 협동역량에 간접적 인 영향을 미치는 3 개의 경로가 발견되었다. 우선 부모의 긍정 적 양육행동은 또래관계 $(\beta=.49, p<.001)$ 에, 또래관계는 협동 역량 $(\beta=.68, p<.001)$ 에 정적인 영향을 미치는 것으로 나타남
으로써 부모의 긍정적 양육행동이 또래관계를 통해 협동역량 에 간접적 영향을 미치는 경로가 제시되었다. 둘째, 부모의 긍 정적 양육행동은 그릿 $(\beta=.17, p<.001)$ 에, 그릿은 협동역량 $(\beta$ $=.30, p<.001)$ 에 정적인 영향을 미쳐 부모의 긍정적 양육행동 이 그릿을 통해 협동역량에 간접적 영향을 미치는 경로가 보 
고되었다. 셋째, 부모의 긍정적 양육행동은 또래관계 $(\beta=.49$, $p<.001)$ 에 유의미한 정적 영향을 미쳤고, 또래관계는 그릿에 정적인 영향 $(\beta=.54, p<.001)$ 을, 그리고 그릿은 협동역량에 정적인 영향 $(\beta=.30, p<.001)$ 을 미침으로써 부모의 긍정적 양 육행동이 또래관계와 그릿의 순차적 매개를 통해 협동역량에 간접적 영향을 미치는 경로가 발견되었다.

이어서, 이상에서 언급된 부모의 긍정적 양육행동이 또래관 계와 그릿을 통해 협동역량에 영향을 미치는 전반적인 간접적 경로의 통계적 유의도를 부트스트랩핑 절차를 적용하여 알아 본 결과, 의미 있는 것으로 나타났다 $(B=.60, p<.05)$. 따라서 전 반적인 간접적 경로의 통계적 유의도가 보고됨에 따라, 긍정적 양육행동이 중학생의 협동역량에 미치는 영향에 있어 또래관 계와 그릿의 개별적 - 순차적 매개경로를 팬텀변수를 적용하여 분석한 결과는 Table 4 에 보고되어 있다. 그 결과, 부모의 긍정 적 양육행동이 또래관계의 매개를 통해 협동역량에 영향을 미 치는 경로, 부모의 긍정적 양육행동이 그릿의 매개를 통해 협 동역량에 영향을 미치는 경로, 부모의 긍정적 양육행동이 또래 관계와 그릿의 순차적 매개를 통해 협동역량에 영향을 미치는 경로가 모두 통계적으로 유의미한 것으로 나타났다.

\section{Discussion}

본 연구는 한국 아동 - 청소년 패널 조사 2018 자료를 사용하 여, 부모의 긍정적 양육행동이 중학생의 협동역량에 미치는 직접적 영향과 또래관계와 그릿을 통한 간접적 영향 경로를 살펴보았다. 본 연구의 주요결과를 요약하고 논의하면 다음과 같다.

우선 연구변인들 간의 상관관계 분석 결과, 부모의 긍정 적 양육행동과 또래관계 및 그릿, 협동역량 간에는 정적인 관 계가 제시되었다. 이러한 결과는 부모의 애정 및 관심, 감독 수준이 높을수록 긍정적인 또래관계를 형성하며(Gorrese \& Ruggieri, 2012; Llorca et al., 2017), 부모의 자녀에 대한 애정과 존중 및 기대 수준이 높을수록, 자녀의 그릿 및 협동역량 발 달에 긍정적 영향을 미치는 것으로 보고한(Carlo et al., 2007;

Duckworth, 2016; Kang \& Yang, 2019; S. Lee \& Kwon, 2018; Yang et al., 2014) 여러 선행 연구 결과를 지지한다. 또한 본 연 구 결과, 또래관계와 그릿은 협동역량과, 그리고 또래관계는 그릿과 정적인 상관관계가 보고되었다. 이러한 결과는 또래 와 긍정적인 관계를 형성할수록 협동과 같은 친사회적 성향이 강화되며(H.-L. Kim et al., 2011; Schoeps et al., 2020), 그릿 수
준이 높을수록 친사회적 행동 수준이 높고(Lan et al., 2019; Ryu $\&$ Yang, 2017), 또래관계와 그릿 간에 정적인 관계(Han \& Park, 2018; Lan, 2019)를 보고한 여러 선행 연구 결과와 일관된다.

더욱이 본 연구에서 가정된 연구모델에 대한 구조방정식모 델 분석 결과, 부모 양육행동이 협동역량에 미치는 직접적 영 향은 지지되지 않은 반면 또래관계와 그릿을 통한 간접적 영 향만 통계적으로 유의미하게 나타남으로써 완전 매개모델이 지지되었다. 이러한 결과는 청소년기의 사회적 행동이 또래관 계와 청소년의 개인적 속성에 의해 주로 영향을 받는 것으로 제시한 Vitaro, Tremblay, Kerr, Pagani와 Bukowski (1997)의 주 장을 지지한다. 반면 이 결과는 본 연구와 동일한 한국 아동 청소년 패널 조사 2018에 참여한 4학년 아동의 자료를 분석하 여, 부모의 구조제공이 자녀의 협동역량에 미치는 직접적 영 향과 그릿을 통한 간접적 영향을 보고한 Jeon (2020)의 연구 결 과와 차이가 있다. 이러한 연구 결과의 차이는 두 연구의 연구 대상 및 양육행동 지표의 차이를 통해서 설명될 수 있다. 일반 적으로, 부모가 자녀 발달에 미치는 영향은 직접적인 교육 및 모델링을 통해 이루어지거나 부모가 자녀에 대한 감정과 태 도를 토대로 형성된 정서적 교류를 통해 발생한다(Darling \& Steinberg, 1993). 즉, 부모가 자녀의 협동역량에 미치는 영향은 부모가 협동심을 포함한 친사회성 발달에 가치를 부여하여 직 접적으로 교육 또는 친사회적 행동의 모델이 됨으로써 이루어 지거나 부모와 자녀 간의 정서적 교류와 상호작용을 통해 형 성된 심리 - 사회적 속성을 통해 간접적으로 발생된다. 아동기 는 청소년기에 비해 부모에 대한 의존도가 상대적으로 높은 점을 고려해 볼 때, 협동역량에 대한 직접적 지도와 모델로서 부모의 영향은 또래관계의 영향력이 상대적으로 증가하는 청 소년기에 비해 아동기에 크게 나타날 수 있다. 더욱이 본 연구 는 긍정적 양육행동의 지표로 따스함, 자율성 지지, 구조제공 을 사용한 반면 Jeon (2020)의 연구에서는 부모의 자율성 지지 와 구조제공을 2 개의 잠재변인으로 적용하였다. 그 결과, 긍정 적 양육행동의 측정치로, 따스함, 자율성 지지, 구조제공 요인 을 사용한 본 연구와 달리 Jeon (2020)의 연구에서는 부모의 구 조제공 요인에 한해서 협동역량에 미치는 직접적인 영향과 그 릿을 통한 간접적 영향이 모두 보고되었다. 이러한 Jeon (2020) 의 연구 결과를 통해, 자녀 행동에 대한 지도와 친사회성과 같 은 사회적 가치에 대한 설명과 관련된 구조제공 요인이 자녀 의 자율성 지지 및 따스함과 같은 전반적인 양육태도와 정서 적 분위기와 관련된 요인에 비해 부모의 권위 및 의존도가 상 대적으로 높은 아동기의 협동역량에 미치는 직접적인 영향이 크다는 점이 시사되고 있다. 
또한 본 연구 결과 부모의 긍정적 양육행동이 협동역량에 미치는 영향에 있어 또래관계의 매개효과가 제시된 점은 부모 의 양육행동과 또래관계 및 또래관계와 협동역량 간의 관계 를 규명한 여러 선행 연구들을 통해 설명이 가능하다. 즉, 부 모 양육행동이 긍정적이고 지지적일수록, 자녀는 이러한 관계 의 요소를 또래관계에 전이시켜 또래와 긍정적인 관계를 형 성한다(Bowlby, 1982; Gorrese \& Ruggieri, 2012). 더욱이 또래 와 긍정적인 관계를 형성할수록, 청소년은 또래로부터 학교생 활적응에 필요한 도구적 - 정서적 지원을 제공받고, 또래관계 를 통해 사회구조와 사회구성원으로서 역할을 학습하며(H.L. Kim et al., 2011), 집단 과제상황에서 또래와 함께 공동의 목 표를 위해 자신 및 타 구성원의 행동을 지지하고 조절하며 협 력하는 과정을 경험함으로써 협동역량이 강화된다(Panadero $\&$ Järvelä, 2015). 또한 청소년은 자신과 유사한 행동성향과 가 치관을 보이는 또래를 친구로 선택하는 호모필리 성향으로 인 해 긍정적인 부모 양육행동을 통해 친사회적 성향을 가질 경 우 자신과 유사한 행동 성향을 가진 또래를 선택하여 교류함 으로써 친사회성이 강화될 수 있다(Goodwin et al., 2012; Shin, 2017). 특히 부모의 긍정적 양육행동이 또래관계를 통해 협동 역량에 정적인 영향을 미치는 것으로 제시된 본 연구 결과는 긍정적인 부모 양육행동이 학교 내 대인관계와 학습활동 적응 에 미치는 영향에 있어 또래애착의 매개효과를 규명한 H.-J. Kim과 Hong (2015)의 연구 결과와 흐름을 같이 한다.

한편 본 연구에서 청소년의 그릿이 부모의 긍정적 양육행 동과 협동역량을 매개하는 것으로 나타난 결과는 그릿과 관련 된 양육행동 및 협동역량의 속성을 통해 설명될 수 있다. 본 연 구의 긍정적 부모 양육행동은 자녀에 대한 애정과 관심, 자율 성 지지, 자녀의 행동에 대한 지도와 감독의 요소로 이루어져 있으며, 이러한 요소들은 자녀가 스트레스 직면 시, 이를 완화 할 수 있는 정서적 안정의 기반을 제공하며, 높은 자기통제 및 성취동기, 성실성과 관련된다(Howard, Nicholson, \& Chesnut, 2019). 따라서 그릿은 자기통제 및 성실성과 유사한 구인이므 로(Duckworth et al., 2007), 부모의 긍정적 양육행동 수준이 높 을수록 그릿 발달을 조장하게 된다. 또한 협동역량은 속성상 그릿의 구성 요인인 목표에 대한 지속적인 관심과 목표달성 을 위한 노력 및 성실성과 밀접하게 관련된 점을 고려해 볼 때 (Jeon, 2020), 부모의 긍정적 양육행동이 그릿을 통해 협동역 량에 영향을 미치는 경로가 설명된다.

그리고 본 연구를 통해 부모의 긍정적인 양육행동이 또래 관계와 그릿의 순차적 매개과정을 통해 협동역량에 영향을 미 치는 경로가 지지되었다. 중학교에서의 교과 및 비교과 활동
은 목표를 동반한 소집단 협동학습 형태로 이루어지는 경우가 많다. 특히 소집단 협동학습 활동에 함께 참여하는 구성원은 주로 동일 연령의 또래로, 또래와 긍정적인 관계를 형성할수 록 또래는 협동에 대한 모델이 되고 어려움과 난관이 있을 경 우 지원을 제공하며 공동의 목표달성을 위해 협력적 조절 기 능을 함께 수행하기도 한다. 따라서 또래와 긍정적 관계를 형 성할수록 또래는 협동이 요구되는 상황에서 비계(scaffolding) 역할을 수행하여 목표에 대한 흥미유지와 지속적인 노력과 관련된 그릿 발달에 긍정적인 영향을 미침으로써(King et al., 2018; Lan, 2019; Panadero \& Järvelä, 2015), 궁극적으로 청소년 의 협동역량을 강화한 것으로 설명된다.

이상에서 언급한 본 연구의 주요결과를 통해 중학교 1학년 학생의 협동역량을 강화하기 위한 부모교육 및 학교교육의 방 향이 제시된다. 우선 청소년의 협동역량에 직접적으로 영향을 미치는 또래관계와 그릿의 중요성이 부각됨에 따라 이와 관련 된 긍정적인 부모 양육행동을 강화하기 위한 부모교육이 활성 화될 필요가 있다. 특히 초등학교와 다른 교육환경 및 대인관 계의 변화가 크게 일어나는 중학교 1학년 자녀의 학부모를 대 상으로, 학교 또는 지역사회기관에서 긍정적인 또래관계 형성 및 그릿 발달에 초점을 맞춘 초. 중 전환기 부모교육이 적극 적으로 운영되어야 한다. 지역의 부모교육 관련 기관의 경우 (예: 건강가정지원센터, 육아종합지원센터) 주로 영유아기 및 아동기 자녀를 둔 부모교육에 중점을 두어 중학교 시기의 자 녀의 사회성 발달 관련 부모교육은 상대적으로 소홀시 되어져 왔다. 따라서 중학교 시기의 자녀의 협동역량 및 또래관계, 그 릿 발달과 관련된 부모교육의 내용을 강화할 필요가 있다. 그 리고 학교에서는 자유학기제 등을 활용하여 학생들의 그릿 및 협동역량 발달을 촉진할 수 있는 다양한 체험 프로그램 개발 이 필요하며, 프로그램 운영 시 또래와 함께 하는 협동학습 형 태로 진행하는 것이 바람직하다. 특히 이러한 프로그램에서 부모와 교사는 학생들의 활동을 지지하고 안내하는 역할을 수 행하여야 한다.

본 연구는 기존의 연구들이 주로 청소년의 친사회적 행동 또는 미시적 대인관계역량에 초점을 맞추어 환경 및 개인 변 인의 영향을 규명한 것과 달리 사회 집단에서 공동의 과업을 수행하는 과정에서 요구되는 협동역량에 초점을 맞추어 부모 양육행동 및 또래관계와 그릿이 영향을 미치는 복합적 경로를 살펴본 점에서 의의가 있다. 특히 협동역량이 다른 대인관계 역량과 달리 집단의 목표달성을 위해 자신 및 타인의 행동과 정서, 사고 등에 대한 협력적 조절과정을 수반하는 점을 고려 하여 목표달성에 대한 노력 및 자기통제와 관련된 구인인 그 
릿의 영향력을 살펴본 점도 주목할 필요가 있다. 또한 기존의 연구들이 주로 학업적 - 직업적 성취에 대한 그릿의 영향을 제 시한 것과 달리 본 연구는 또래관계와 그릿의 관련성을 경험 적으로 입증한 점도 의미가 있다.

마지막으로 본 연구의 한계점을 토대로, 추후 연구방향을 제안하면 다음과 같다. 첫째, 본 연구는 협동역량에 초점을 맞 추어 부모 및 또래관계, 그릿의 영향을 살펴보았으나, 향후 연 구에서는 공동의 목표를 가진 사회 집단에서 발현되는 또 다 른 역량인 리더십에 초점을 맞추어 이에 대한 다양한 변인들 의 영향이 규명될 필요가 있다. 둘째, 본 연구는 중학교 1학년 학생을 대상으로, 사실상 변인들 간의 상관관계에 기초한 횡 단적 연구 설계에 기반하므로, 향후 부모의 양육행동이 시간 에 따라 또래관계 및 그릿, 협동역량에 영향을 미치는 종단적 인과관계를 규명하여 보다 효율적인 지도방안을 모색할 필요 가 있다. 더욱이 협동역량은 또래관계에도 영향을 미칠 수 있 으므로(Blair \& Perry, 2019), 두 변인 간의 상호 인과관계에 대 한 규명이 이루어질 필요가 있다.

\section{Notes}

This article was presented at the 2020 Annual Fall Online Conference of the Korean Association of Child Studies.

\section{Conflict of Interest}

No potential conflict of interest relevant to this article was reported.

\section{References}

\section{In English}

Armsden, G. C., \& Greenberg, M. T. (1987). The inventory of parent and peer attachment: Individual differences and their relationship to psychological well-being in adolescence. Journal of Youth and Adolescence, 16, 427-454. doi:10.1007/ BF02202939

Blair, B. L., \& Perry, N. B. (2019). Parental sensitivity and friendship development: The mediating role of cooperation. Social Development, 28(1), 106-119. doi:10.1111/sode.12332
Bowlby, J. (1982). Attachment and loss: Retrospect and prospect. American Journal of Orthopsychiatry, 52(4), 664-678. doi:10.1111/j.1939-0025.1982.tb01456.x

Carlo, G., Mc Ginley, M., Hayes, R., Batenhorst, C., \& Wilkinson, J. (2007). Parenting styles or practices? Parenting, sympathy, and prosocial behaviors among adolescents. The Journal of Genetic Psychology, 168(2), 147-176. doi:10.3200/GNTP. 168.2.147-176

Coleman, J. C. (1978). Current contradictions in adolescent theory. Journal of Youth and Adolescence, 7, 1-11. doi:10.1007/ BF01538683

Darling, N., \& Steinberg, L. (1993). Parenting style as context: An integrative model. Psychological Bulletin, 113(3), 487-496. doi:10.1037/0033-2909.113.3.487

Duckworth, A. L. (2016). Grit: The power of passion and perseverance (Unabridged ed.). New York: Simon \& Scribner.

Duckworth, A. L., Peterson, C., Matthews, M. D., \& Kelly, D. R. (2007). Grit: Perseverance and passion for long-term goals. Journal of Personality and Social Psychology, 92(6), 10871101. doi:10.1037/0022-3514.92.6.1087

Eskreis-Winkler, L., Shulman, E. P., Beal, S. A., \& Duckworth, A. L. (2014). The grit effect: Predicting retention in the military, the workplace, school and marriage. Frontiers in Psychology, 5, 1-12. doi:10.3389/fpsyg.2014.00036

Goodwin, N. P., Mrug, S., Borch, C., \& Cillessen, A. H. N. (2012). Peer selection and socialization in adolescent depression: The role of school transitions. Journal of Youth and Adolescence, 41, 320-332. doi:10.1007/s10964-011-9723-x

Gorrese, A., \& Ruggieri, R. (2012). Peer attachment: A metaanalytic review of gender and age differences and associations with parent attachment. Journal of Youth and Adolescence, 41, 650-672. doi:10.1007/s10964-012-9759-6

Hadwin, A., Järvelä, S., \& Miller, M. (2017). Self-regulation, coregulation and shared regulation in collaborative learning environments. In D. H. Schunk \& J. A. Greene (Eds.), Handbook of self-regulation of learning and performance (2nd ed., pp. 83-106). New York: Routledge.

Howard, J. M., Nicholson, B. C., \& Chesnut, S. R. (2019). Relationships between positive parenting, overparenting, grit, and academic success. Journal of College Student Development, 6O(2), 189-202. doi:10.1353/csd.2019.0018

Jin, H., Wang, W., \& Lan, X. (2019). Peer attachment and academic procrastination in Chinese college students: A moderated mediation model of future time perspective and grit. Frontiers in Psychology, 10, 1-11. doi:10.3389/fpsyg.2019.02645

King, C. D., Hilton, B. T., Greenfield, S. F., Mc Hugh, R. K., Griffin, M. L., Weiss, R. D., \& Ressler, K. J. (2020). Anxiety sensitivity and grit as mediators between childhood abuse and relapse risk for substance use. Child Abuse \& Neglect, 107, 1-8. doi:10.1016/j.chiabu.2020.104568 
King, K. M., Mc Laughlin, K. A., Silk, J., \& Monahan, K. C. (2018). Peer effects on self-regulation in adolescence depend on the nature and quality of the peer interaction. Development and Psychopathology, 30(4), 1389-1401. doi:10.1017/S0954579417001560

Lan, X. (2019). Peer attachment and grit in adolescence and emerging adulthood. PsyCh Journal, 8(4), 520-521. doi:10.1002/pchj. 289

Lan, X., Marci, T., \& Moscardino, U. (2019). Parental autonomy support, grit, and psychological adjustment in Chinese adolescents from divorced families. Journal of Family Psychology, 33(5), 511-520. doi:10.1037/fam0000514

Llorca, A., Cristina Richaud, M., \& Malonda, E. (2017). Parenting, peer relationships, academic self-efficacy, and academic achievement: Direct and mediating effects. Frontiers in Psychology, 8, 1-11. doi:10.3389/fpsyg.2017.02120

Macho, S., \& Ledermann, T. (2011). Estimating, testing, and comparing specific effects in structural equation models: The phantom model approach. Psychological Methods, 16(1), 34-43. doi:10.1037/a0021763

Malonda, E., Llorca, A., Mesurado, B., Samper, P., \& Mestre, M. V. (2019). Parents or peers? Predictors of prosocial behavior and aggression: A longitudinal study. Frontiers in Psychology, 10, 1-12. doi:10.3389/fpsyg.2019.02379

Mc Laughlin, K. A., Hatzenbuehler, M. L., \& Hilt, L. M. (2009). Emotion dysregulation as a mechanism linking peer victimization to internalizing symptoms in adolescents. Journal of Consulting and Clinical Psychology, 77(5), 894904. doi:10.1037/a0015760

Meldrum, R. C., \& Hay, C. (2012). Do peers matter in the development of self-control? Evidence from a longitudinal study of youth. Journal of Youth and Adolescence, 41, 691703. doi:10.1007/s10964-011-9692-0

Panadero, E., \& Järvelä, S. (2015). Socially shared regulation of learning: A review. European Psychologist, 20(3), 190-203. doi:10.1027/1016-9040/a000226

Rychen, D. S., \& Salganik, L. H. (2003). Key competencies for a successful life and a well-functioning society. Cambridge, MA: Hogrefe \& Huber Publishers.

Schoeps, K., Mónaco, E., Cotolí, A., \& Montoya-Castilla, I. (2020). The impact of peer attachment on prosocial behavior, emotional difficulties and conduct problems in adolescence: The mediating role of empathy. PLoS ONE 15(1), 1-18. doi:10.1371/journal.pone.0227627

Shin, H. (2017). Friendship dynamics of adolescent aggression, prosocial behavior, and social status: The moderating role of gender. Journal of Youth and Adolescence, 46, 2305-2320. doi:10.1007/s10964-017-0702-8

Vitaro, F., Tremblay, R. E., Kerr, M., Pagani, L., \& Bukowski, W. M. (1997). Disruptiveness, friends' characteristics, and delinquency in early adolescence: A test of two competing models of development. Child Development, 68(4), 676689. doi: $10.2307 / 1132118$

West, S. G., Finch, J. F., \& Curran, P. J. (1995). Structural equation models with nonnormal variables: Problems and remedies. In R. H. Hoyle (Ed.), Structural equation modeling: Concepts, issues, and applications (pp. 56-75). Thousand Oaks, CA: Sage Publications.

Wilkinson, R. B. (2004). The role of parental and peer attachment in the psychological health and self-esteem of adolescents. Journal of Youth and Adolescence, 33, 479-493. doi:10.1023/ b:joyo.0000048063.59425.20

\section{In Korean}

Bae, S. M., Hong, J. Y., \& Hyun, M. H. (2015). A validation study of the Peer Relationship Quality Scale for adolescents. Korean Journal of Youth Studies, 22(5), 325-344.

Chang, H.-L., \& Chung, I.-J. (2013). The effects of parenting attitudes on adolescent prosocial behavior and aggression mediated by self-esteem. Korean Journal of Family Social Work, 40, 33-61. doi:10.16975/kjfsw.2013..40.002

Choi, H., Lee, S., Kim, H. (2020). Latent profile analysis according to the achievement motivation and team-efficacy of pre-early childhood teachers' in collaborative learning: Difference in collective intelligence by latent group. Journal of Learner-Centered Curriculum and Instruction, 20(15), 961-981. doi:10.22251/jlcci.2020.20.15.961

Choi, K. O. (2015). A study on the factors influencing interpersonal competence of youths-Focusing on the effects of social capital-. Journal of the Korean Society of Child Welfare, (51), 251-286.

Gil, H., \& Yu, S. (2020). An analysis of relation between selfdirected, cooperative competencies and college life adaptation focusing on the mediation effect of problem solving of pre-service early childhood teachers. Journal of Learner-Centered Curriculum and Instruction, 20(6), 779801. doi:10.22251/jlcci.2020.20.6.779

Han, S., \& Park, Y. (2018). Exploring home and school contextual factors related to adolescents' grit and its change. The Journal of Yeolin Education, 26(4), 175-201. doi:10.18230/ tjye.2018.26.4.175

Jeon, R. Y. (2020). The effects of parental autonomy support and structure on child's cooperation with child's grit as a mediator. Journal of Learner-Centered Curriculum and Instruction. 20(11), 117-139. doi:10.22251/jlcci.2020.20.11.117

Kang, M. S., \& Yang, S. (2019). On the mediating effects of harmonious.obsessive passion and grit in the relationship between parent attachment and life satisfaction. The Korean Journal of Developmental Psychology, 32(2), 79-101. 
doi:10.35574/KJDP.2019.06.32.2.79

Kim, C. H., Eom, M. Y., Kim, K. H., Kim, C. M., Park, J. H., Park, H.-J.,...Lee, S. D. (2013). A Study for developing student competency index (Report No. RR 2013-23). Retrieved from Korean Educational Development Institute web site: https://www.kedi.re.kr/

Kim, E. H., \& Kim, M.-J. (2020). The effect of parents' negative parenting behaviors on the psychological wellbeing of college students: Mediating grit and academic adjustment. Korean Journal of Youth Studies, 27(5), 405-431. doi:10.21509/KJYS.2020.05.27.5.405

Kim, H.-J., \& Hong, S.-H. (2015). The mediating effects of peer attachment and self-esteem on the relationships between parenting attitude and school adjustment. The Journal of Korea Elementary Education, 26(1), 413-429. doi:10.20972/ kjee.26.1.201503.413

Kim, H.-L., Kim, J.-H., \& Chung, I.-J. (2011). The effects of peer group on adolescent prosocial behavior-Focusing on the comparison between the peer influence model and the individual characteristics model-. Journal of the Korean Society of Child Welfare, (36), 261-288.

Kim, H.-M., \& Hwang, M.-H. (2015). Validation of the Korean Grit Scale for children. The Journal of Education, 35(3), 6374. doi:10.25020/je.2015.35.3.63

Kim, T., \& Lee, E. (2017). Validation of the Korean version of Parents as Social Context Questionnaire for adolescents: PSCQ_KA. Korean Journal of Youth Studies, 24(3), 313333. doi:10.21509/KJYS.2017.03.24.3.313

Kim, T., Oh, M., \& Lee, Y. (2015). Youth competency index measurement and international comparison study: IEA ICCS 2016 (Report No. 15-R18-3). Retrieved from NYPI web site: https://www.nypi.re.kr

Lee, M.-J., \& Kim, Y.-G. (2018). A qualitative analysis on the factors of family, peer, and school of adolescent doing school violence. Asia-pacific Journal of Multimedia Services Convergent with Art, Humanities, and Sociology, 8(2), 445456. doi:10.35873/ajmahs.2018.8.2.044

Lee, S., \& Kwon, J. (2018). Multiple mediating effects of interpersonal relationship ability and altruism on the relationship between parental attitudes and multicultural acceptability of adolescents. Asian Journal of Education, 19(4), 969-993. doi:10.15753/aje.2018.12.19.4.969

Ministry of Education. (2019). 2019nyeon 1cha haggyopoglyeog siltaejosa gyeolgwa balpyo [2019년 1차 학교폭력 실태조사
결과 발표]. Retrieved from MOE web site: https://www. moe.go.kr/boardCnts/view.do?boardID $=294 \&$ boardSeq $=7$ 8346\&lev $=0$ \& $\mathrm{m}=02$

National Youth Policy Institute. (2018). Korean children \& youth panel 1st survey [Data file and code book]. Retrieved from NYPI web site: https://www.nypi.re.kr/archive

Park, J.-H., \& Hong, H.-J. (2018). An exploratory study of national curriculum standards to promote cooperation. The Journal of Curriculum Studies, 36(3), 1-27.

Park, S., Park, Y., \& Kim, Y. (2018). The mediated effects of emotion regulation style in the relationships between parenting attitudes perceived by adolescents and social competence. Journal of Learner-Centered Curriculum and Instruction, 18(7), 393-410. doi:10.22251/jlcci.2018.18.7.393

Ryu, Y.-J., \& Yang, S. (2017). On the mediating effects of grit and prosocial behavior in the relationship between intrinsic vs. prosocial motivation and life satisfaction. The Korean Journal of Developmental Psychology, 30(4), 93-115.

Sung, E., Choi, C., Kim, H., Oh, S.-Y., \& Jin, S.-H. (2015). The development and validation of Korean Youth Competency Index (KYCI) and definition. Asian Journal of Education, 16(2), 117-144. doi:10.15753/aje.2015.16.2.005

Yang, N.-M., Park, H.-J., \& Lee, D.-G. (2014). The relationship between warm parenting style and children's interpersonal conflict-resolution ability in middle school students: The mediation effects of emotional support and self-esteem. Korean Journal of Counseling, 15(4), 1515-1529. doi:10.15703/ kjc.15.4.201408.1515

Yu, J. (2012). Ujongpil gyosu-ui gujobangjeongsigmodel gaenyeomgwa ihae Amos 4.0-20.0 gong-yong [우종필 교수의 구조방정식 모델 개념과 이해 Amos 4.0-20.0 공용]. Seoul: Hanarae Academy.

\section{ORCID}

Yangmi Lim https://orcid.org/0000-0003-1084-7144

Received December 28, 2020

Revision received January 21, 2021

Accepted February 8, 2021 